\title{
A Sol-Gel Modified Alternative Nafion-Silica Composite Membrane for Polymer Electrolyte Fuel Cells
}

\author{
A. K. Sahu, G. Selvarani, S. Pitchumani, P. Sridhar, ${ }^{*}$ and A. K. Shukla*,z
}

Central Electrochemical Research Institute, Karaikudi-630 006, India

Nafion-silica composite membranes are fabricated by embedding silica particles as inorganic fillers in perfluorosulfonic acid ionomer by a novel water hydrolysis process. The process precludes the use of an added acid but exploits the acidic characteristic of Nafion facilitating an in situ polymerization reaction through a sol-gel route. The use of Nafion as acid helps in forming silica/siloxane polymer within the membrane. The inorganic filler materials have high affinity to water and assist proton transport across the electrolyte membrane of the polymer electrolyte fuel cell (PEFC) even under low relative humidity (RH) conditions. In the present study, composite membranes have been tested in hydrogen/oxygen PEFCs at varying RH between 100 and $18 \%$ at elevated temperatures. Attenuated total reflectance-Fourier transform infrared spectroscopy and scanning electron microscopy studies suggest an evenly distributed siloxane polymer with $\mathrm{Si}-\mathrm{OH}$ and $\mathrm{Si}-\mathrm{O}-\mathrm{Si}$ network structures in the composite membrane. At the operational cell voltage of $0.4 \mathrm{~V}$, the PEFC with an optimized silica-Nafion composite membrane delivers a peak power density value five times higher than that achievable with a PEFC with conventional Nafion-1135 membrane electrolyte while operating at a $\mathrm{RH}$ of $18 \%$ at atmospheric pressures.

(C) 2006 The Electrochemical Society. [DOI: 10.1149/1.2401031] All rights reserved.

Manuscript submitted August 1, 2006; revised manuscript received September 8, 2006

Available electronically December 15, 2006.

The polymer electrolyte fuel cell (PEFC) is an attractive power source for a variety of applications ${ }^{1}$ due to its high efficiency and environment-friendly characteristics. The current PEFC technology utilizes perfluorosulfonic acid (PFSA) polymer membranes, e.g., Nafion, as electrolyte and hence is limited to low-temperature applications. In order to realize the optimum PEFC performance, the Nafion membrane needs to be fully wet as the proton conduction in Nafion relies on the dissociation of protons from the constituent $\mathrm{SO}_{3} \mathrm{H}$ groups in the presence of water. ${ }^{2}$ However, the performance of PEFCs is enhanced at elevated temperatures by improved kinetics of the cathode and anode reactions and the reduction in adsorption of poisoned species such as CO. ${ }^{3-6}$ To this end, Nafion-composite membranes suitably modified with ceramic/inorganic fillers, namely $\mathrm{SiO}_{2}, \mathrm{TiO}_{2}, \mathrm{ZrO}_{2}$, etc., are widely used ${ }^{7-13}$ to facilitate proton conductivity in the membranes at elevated temperatures even under low relative humidity $(\mathrm{RH})$ conditions.

Watanabe et al. ${ }^{14}$ have employed modified Nafion membrane fabricated by incorporating nanosized particles of $\mathrm{SiO}_{2}, \mathrm{TiO}_{2}, \mathrm{Pt}$, $\mathrm{Pt}-\mathrm{SiO}_{2}$, and $\mathrm{Pt}-\mathrm{TiO}_{2}$ to alleviate the humidification requirements of PEFCs. When operated under low humidification, PEFCs with an alternative membrane reportedly exhibited lower ohmic drops in relation to Nafion. In situ platinum particulates with sorption of the water produced on the incorporated oxide fillers attribute such an improvement accompanied with suppression of hydrogen crossover. The benefits of these composite membranes appear to be in the steady operation of PEFCs at about $130^{\circ} \mathrm{C}$ due to the higher rigidity of the membranes in relation to commercial Nafion membranes, while operating under fully wet conditions. Costamagna et al. ${ }^{2}$ have also reported similar findings for their zirconium-phosphateincorporated Nafion-115 membranes. Adjemian et al. ${ }^{15}$ have studied Nafion membranes modified separately with silica and zirconium phosphate particles and have found the silica modified Nafion membranes to be more robust with higher water retention and superior performance.

Staiti et al. ${ }^{16}$ and Ramani et al. ${ }^{17}$ have investigated Nafion-silica composite membranes doped with heteropoly acids, namely phosphotungstic acid (PWA) and silicotungstic acid (SiWA), for application in a direct methanol fuel cell (DMFC) operating at $145^{\circ} \mathrm{C}$. This membrane shows better water retention and thermomechanical properties in relation to commercial Nafion membranes. Aricò et al. ${ }^{18}$ have reported attractive proton conductivity for their inorganicacid-doped composite membranes, namely $\mathrm{Nafion}-\mathrm{SiO}_{2}$ and

* Electrochemical Society Active Member.

${ }^{\mathrm{z}}$ E-mail: shukla@sscu.iisc.ernet.in
Nafion-PWA-SiO ${ }_{2}$, between 90 and $140^{\circ} \mathrm{C}$. Adjemian et al. ${ }^{15}$ and Jung et al. ${ }^{19}$ have modified Nafion-115 membrane by a sol-gel reaction with tetraethoxysilane (TEOS) and have studied its utility both in a PEFC and a DMFC. A nanocomposite, recast Nafion-hybrid membrane containing titania as inorganic filler has been reported ${ }^{20}$ and it is found that induction of titania particles endows the composite membrane with good mechanical and thermal resistance and improves its water uptake and ion exchange capacity in relation to commercial Nafion membranes.

In the literature, membranes with inorganic fillers have been fabricated by a variety of techniques. Conventionally, water-absorbing inorganic oxides are embedded into the pores of a porous polymer matrix by several methods. One method includes impregnating inorganic oxide particles as fine powders ${ }^{21-24}$ into the pores of a porous polymer matrix. Another method includes the addition of a precursor, generally as acidic metal alkoxides solution, ${ }^{19,25-27}$ into the pores of a porous polymer matrix and then converting the precursor material into the desired proton-conducting oxide. Still another method includes precipitating a mixture of the ion-conducting oxide and a polymer matrix from solution and casting the precipitate into a membrane. The impregnation of inorganic fillers also includes converting a soluble precursor to a proton-conducting metal oxide into an aqueous solution containing an emulsion or suspension of a polymer and concomitantly precipitating the polymer and the metal oxide. In most of the cases, ${ }^{11,13,15}$ the solid polymer electrolyte, such as Nafion, is soaked in the inorganic metal alkoxide precursor or alcoholic solution of one or more metal alkoxides till the desired amount of the inorganic filler permeates through the pores of Nafion. After soaking the surface, the membrane is copiously rinsed to wash away surface metal alkoxide, which is followed by hydrolyzing the metal alkoxide in the membrane with water.

Incorporating the inorganic fillers into the polymeric matrix by the above process may not be homogeneous as, in such fillings, it is possible that some portions of the matrix may contain little or no oxide. It is also possible to find enriched concentrations of the filler particles in the bottom part of the membrane due to the sedimentation effect of the heavier ceramic/inorganic fillers. As a result, the solid fillers in the composite membranes are devoid of imparting sufficient proton conductivity in the membrane under dry conditions.

The present study obviates the aforesaid disadvantages. An in situ sol-gel process is described wherein a homogeneous, transparent, and less viscous inorganic sol is first prepared by a controlled hydrolysis/polymerization route, followed by a novel water hydrolysis to metal alkoxide without any external acidic or basic environment. Subsequently, the required amount of the sol is incorporated 
into the polymer matrix. The less viscous sol enters the fine pores of PFSA and due to the acidic nature of the latter forms $\mathrm{Si}-\mathrm{OH}$ network in the pores, which on heating at $90^{\circ} \mathrm{C}$ under vacuum culminate as $\mathrm{Si-O}-\mathrm{Si}$ linkages, forming a film of almost the same thickness as Nafion-1135, namely $90 \mu \mathrm{m}$. As a result, a visibly transparent polymer film is obtained without any particle/phase segregation. The composite membrane exhibits appreciable proton conductivity at elevated temperatures under low RH. Performance of these composite membranes is evaluated in a PEFC at varying $\mathrm{RH}$ at elevated temperatures. A peak power density of $340 \mathrm{~mW} / \mathrm{cm}^{2}$ is obtained with such a $\mathrm{PEFC}$ at $100^{\circ} \mathrm{C}$ and at atmospheric pressure. A PEFC with Nafion-1135 membrane electrolyte failed to show any sensible performance when operated under similar conditions.

\section{Experimental}

Nafion-1135 (DuPont) membrane is boiled with 30 vol \% nitric acid for $1 \mathrm{~h}$ to expel metal and organic impurities followed by copious rinsing and washing with distilled water. The membrane is then boiled in $5 \mathrm{vol} \% \mathrm{H}_{2} \mathrm{O}_{2}$ for 30 min followed by rinsing and washing in distilled water. Finally, the membrane is boiled in $1 \mathrm{M}$ $\mathrm{H}_{2} \mathrm{SO}_{4}$ for $1 \mathrm{~h}$, followed by washing with distilled water. All cleaned membranes are stored in deionized water for later use.

TEOS (98\%, Acros Organics), isopropyl alcohol (IPA) (99\%, Merck), and deionized water $\left(\mathrm{H}_{2} \mathrm{O}\right)$ are used as the starting materials. Silica sol of TEOS + IPA $+\mathrm{H}_{2} \mathrm{O}$ is obtained in a molar ratio of $1: 4: 4$, respectively. The mixture is sonicated for $15 \mathrm{~min}$ to obtain a visibly homogeneous and transparent colloidal suspension. The required amount of sol is then impregnated with 5\% commercial Nafion solution (DuPont) and the resultant admixture is sonicated for another $15 \mathrm{~min}$. The admixture is then transferred to a flat dish followed by its overnight drying in vacuum oven at $90^{\circ} \mathrm{C}$. The composite membrane thus formed is detached by adding water. The thickness of the finished membrane is around $90 \mu \mathrm{m}$. It has not been possible to realize silica-Nafion composite membranes beyond 15 wt $\%$ silica by the above procedure. The presence and distribution of silica particles in the finished membranes is ascertained with the help of a Nexus-670 attenuated total reflectance (ATR)-Fourier transform infrared spectrometer (FTIR) and a JEOL JSM 5400 scanning electron microscope coupled with electron dispersive spectroscope analysis by X-ray (EDAX) facility.

Toray carbon papers (thickness $=0.27 \mathrm{~mm}$ ) are used as backing layers. To the backing layers, diffusion layers comprising $1.5 \mathrm{mg} / \mathrm{cm}^{2}$ of Vulcan XC-72R carbon slurry are applied by a brushing method. In-house-prepared $40 \mathrm{wt} \% \mathrm{Pt}$ catalysts supported onto Vulcan XC-72R carbon $^{28}$ is coated onto the diffusion layers in a similar manner. The catalyst loading on both the anode and the cathode (active area $25 \mathrm{~cm}^{2}$ ) is kept at $0.5 \mathrm{mg} / \mathrm{cm}^{2}$. Membrane electrode assembly (MEA) is obtained by hot pressing under $15 \mathrm{kN}$ at $125^{\circ} \mathrm{C}$ for 3 min. Finally, MEAs are coupled with Teflon gas-sealing gaskets and placed in a single-cell test fixture. The performance evaluation of the PEFCs with Nafion-1135 and silica-Nafion composite membranes is studied at varying RH values between 100 and $18 \%$ in the temperature range $60-100^{\circ} \mathrm{C}$. All the experiments are carried out at atmospheric pressure.

The high humidity in the PEFC $(\approx 100 \% \mathrm{RH})$ is maintained by passing humidified hydrogen and oxygen gases to its anode and cathode sides, respectively, through a humidification bottle containing deionized water with its temperature maintained between 60 and $70^{\circ} \mathrm{C}$. Hot and wet hydrogen and oxygen gases are fed to the anode and cathode sides, respectively, at a flow rate of $1.5 \mathrm{~L} / \mathrm{min}$ controlled by a mass-flow controller.

The RH of the fuel cell depends on the mass of water vapor $(D)$, saturated vapor pressure of water $\left(P_{\text {sat }}\right)$, and moisture content $\left(m_{\mathrm{H}_{2} \mathrm{O}}\right)$. In order to operate the PEFC at varying $\mathrm{RH}$ values, parameters like dew-point temperature (DPT), gas temperature (GT)/gassupply temperature (GST), and dew-point humidification temperature (DPH) are adjusted using an Arbin fuel cell test station (see Table I).

\begin{tabular}{|c|c|c|c|c|}
\hline S1 no. & RH & DPT & GT/GST & DPH \\
\hline 1 & 83 & 80 & 85 & 85 \\
\hline 2 & 66 & 60 & 70 & 70 \\
\hline 3 & 31 & 40 & 65 & 65 \\
\hline 4 & 18 & 25 & 60 & 60 \\
\hline
\end{tabular}

The mass of water vapor $(D)$ in gram per liter retained in the reactant gases could be obtained from the procedure given in the Arbin-002 MITS Pro-FCTS 5.0-FCTS User Manual. The mass of water (moisture content, $m_{\mathrm{H}_{2} \mathrm{O}}$ ) delivered to the fuel cell is obtained by multiplying the mass flow rate (FR) of each of the reactant streams by the appropriate $D$ factor and the run time $(t)$ as follows

$$
m_{\mathrm{H}_{2} \mathrm{O}}=D_{T} \times F R(\text { slpm }) \times t(\min )
$$

The RH at a desired $D$ factor of GT/GST and DPT is given by

$$
R H=D_{\mathrm{DPT}} / D_{\mathrm{GT} / \mathrm{GST}}
$$

After establishing the desired experimental conditions, the polarization data on the PEFC are obtained using a fuel cell test station (model PEM-FCTS-158541) supplied by Arbin Instruments, US. The polarization data are collected point by point and $1 \mathrm{~min}$ is given to the system to come to steady state. The reproducibility of the data is ascertained by repeating the experiments at least twice.

\section{Results and Discussion}

ATR-FTIR spectra for Nafion and silica-Nafion composite membranes are shown in Fig. 1a and b, respectively. In the spectrum for silica-Nafion composite membrane shown in Fig. 1b, most of the characteristic absorption bands due to Nafion seen in Fig. 1a are suppressed. In the spectrum (Fig. 1b), the absorption band at $950 \mathrm{~cm}^{-1}$ is attributed to $\mathrm{Si}-\mathrm{OH}$ stretching vibration and the absorption peak at $800 \mathrm{~cm}^{-1}$ is assigned to the asymmetric stretching vibration due to the $\mathrm{Si}-\mathrm{O}-\mathrm{Si}$ group. ${ }^{15}$ The presence of these absorption bands confirms the existence of silica in the composite membrane.

Figure 2 shows SEM photographs for Nafion-1135 membrane and alternative silica-Nafion composite membrane with varying silica content fabricated during this study. Silica-Nafion composite membranes, as seen in Fig. 2b-d, are homogeneous. Most of the regions in the membrane indicate the absence of silica, suggesting it to be present within the pores of the Nafion matrix. Only a few agglomerated nanosized particles are seen on the membrane surface. The agglomerates increase with increasing silica content in the membrane. EDAX spectrum for the composite membrane shown in Fig. 3 suggests the presence of $\mathrm{Si}$, confirming it to be one of its constituents.

It is well documented that sol-gel polymerization is carried out either in the acidic (Fig. 4a) or the basic (Fig. 4b) catalyst environment to facilitate the reaction and to increase the viscosity of the sol. ${ }^{29}$ In acidulous medium, alkoxide groups get protonated. This leads to electron density withdrawal from the silicon atoms to the alkoxide groups, making the former relatively more electrophilic with the formation of a penta-coordinate transition state. The transition state decays by displacement of an alcohol and forms silicon hydroxides. Thus, the silicon oxide network yields primarily linear/ randomly branched polymer that entangles and forms additional branches, leading to gelation. In a basic medium, water dissociates to produce hydroxyl anions, which facilitate silicon atoms to displace -OR groups. Subsequently, the alkoxide group is removed from the monomer, forming silicon hydroxide. For this situation, the silicon oxide network yields highly branched clusters that do not interpenetrate prior to gelation and behave as discrete clusters. ${ }^{29}$ The acid or base-catalyzed sol could form linear/randomly branched polymer or highly branched clusters, as shown in Fig. 4c. Under 


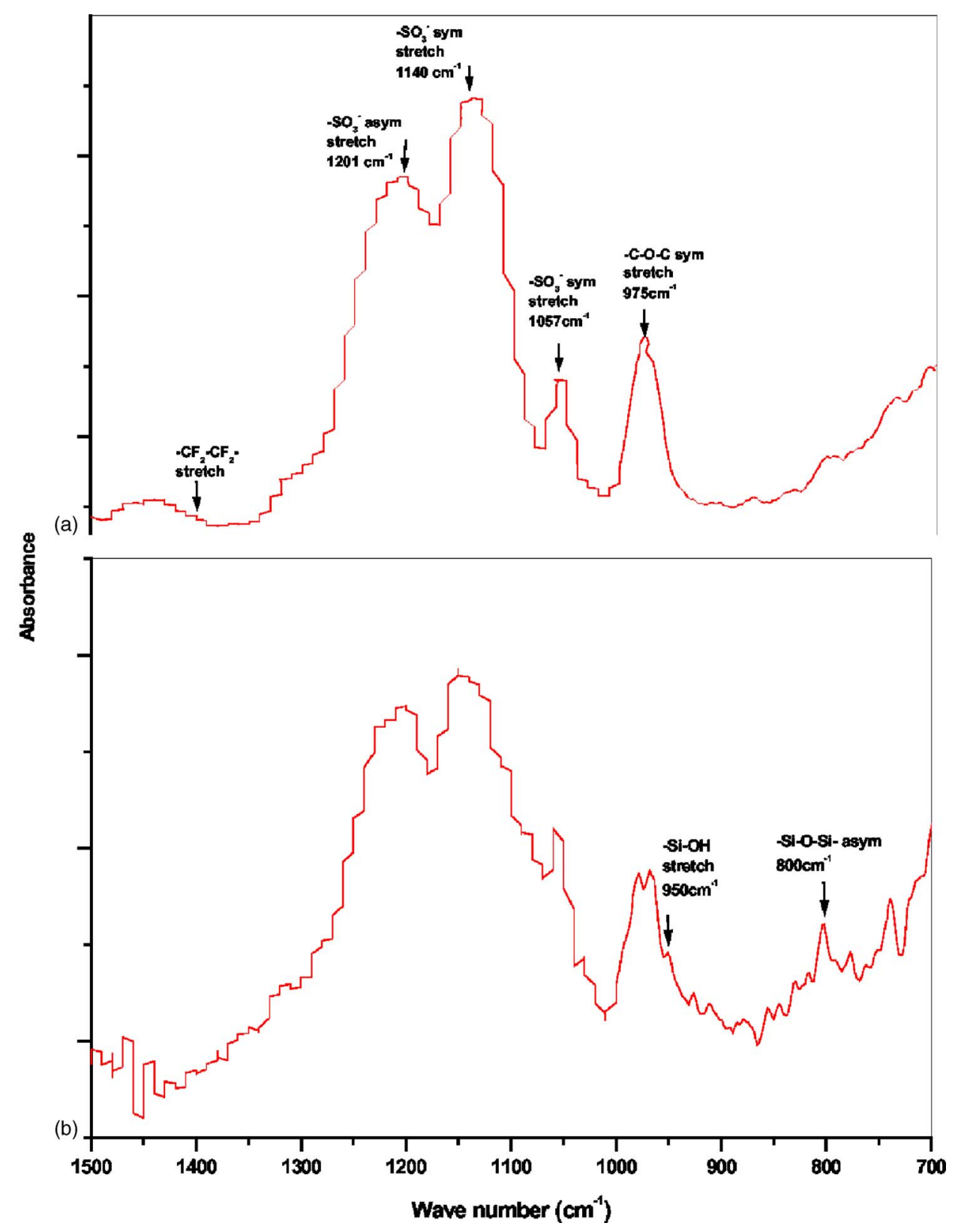

Figure 1. (Color online) ATR-FTIR spectra for (a) Nafion-1135 and (b) silicaNafion composite membranes.

these conditions, the viscous sol may not enter the nanopores of the PFSA ionomer, resulting in an uneven distribution of silica particles in the ionomer matrix. Hence, an alternative approach for sol-gel formulation is desired to produce a homogeneous, transparent, and less viscous silica sol.

This has been possible in this study through the controlled hydrolysis and polymerization, followed by a novel water hydrolysis to metal alkoxide precluding any acid/base environment, as shown in Fig. 5. In the Experimental section, it has been described that the silica sol of TEOS + IPA $+\mathrm{H}_{2} \mathrm{O}$ is obtained in the respective molar ratio of 1:4:4. Although the reactivity of TEOS is less than other inorganic precursors, like $\mathrm{Zr}(\mathrm{OR})_{4}$ and $\mathrm{Ti}(\mathrm{OR})_{4}$, IPA is used to recede the reactivity of TEOS. A small amount of water is then added to decelerate and control the hydrolysis. The sol could be kept long without forming a gel. The transparent and uniform sol is realized only by keeping TEOS + IPA $+\mathrm{H}_{2} \mathrm{O}$ in the respective molar ratio of 1:4:4. This process precludes any acidic or basic catalyst medium and avoids immediate polymerization with concomitant arrest in the increase of the sol viscosity depriving gel formation. Without any acidic or basic catalyst environment, adding only a small amount of deionoized water to the inorganic precursor carries out slow hydrolysis. This helps produce homogeneous, transparent, and less viscous sol. This is considered to be the rate-determining step. Subsequently, the required amount of the sol is allowed to percolate within the polymer matrix. The less viscous sol enters the fine pores of PFSA and, due to the acidic nature of the latter, facilitates the reaction (see Fig. 4a), yielding a linear/randomly branched polymer with $\mathrm{Si}-\mathrm{OH}$ network in the pores of PFSA matrix that on subsequent condensation and heating at $90^{\circ} \mathrm{C}$ under vacuum culminates in $\mathrm{Si}-\mathrm{O}-\mathrm{Si}$ linkages, yielding a film of desired thickness. As a result, a transparent polymer film is obtained without any particle/phase segregation (see Fig. 2).

Performance data for PEFC employing silica-Nafion composite membranes between 80 and $140^{\circ} \mathrm{C}$ under pressurized conditions have been reported by Bocarsly et al. ${ }^{15}$ However, conclusive investigations towards the effect of humidity on silica-Nafion composite membranes are limited. Accordingly, an objective of this study is also to evaluate the performance of our sol-gel-derived silica-Nafion composite membranes in PEFCs at varying $\mathrm{RH}$ values at elevated temperatures under ambient pressure. 


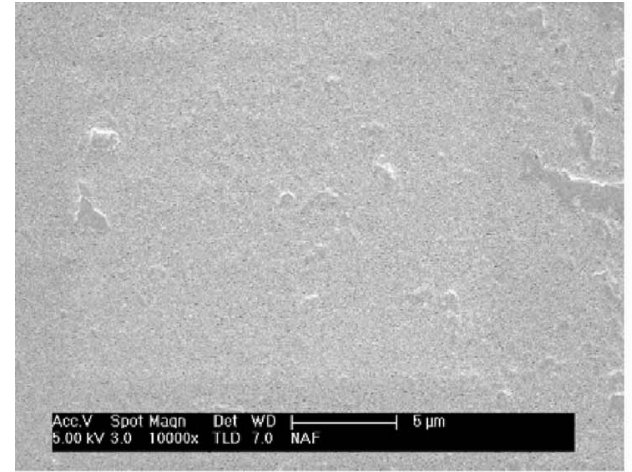

(a)

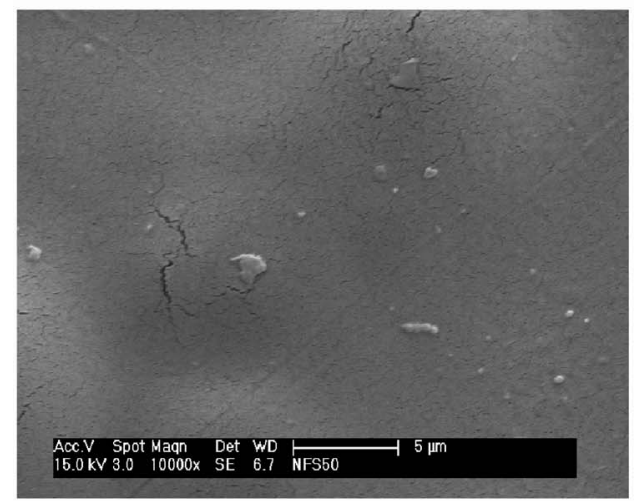

(c)

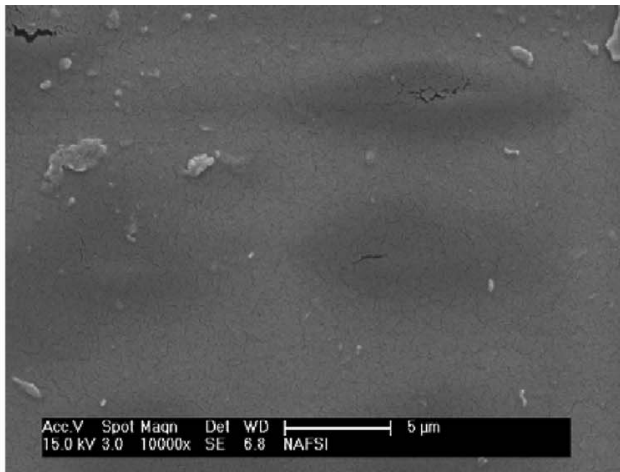

(b)

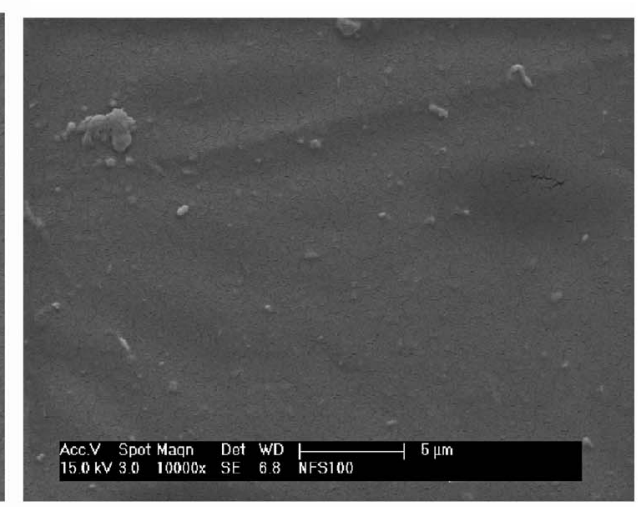

(d)
Figure 2. SEM photographs for (a) Nafion-1135, (b) silica (2.5 wt \%)-Nafion, (c) silica (5 wt \%)-Nafion, and (d) silica (10 wt \%)-Nafion composite membranes.
The performance of the $\mathrm{H}_{2} / \mathrm{O}_{2}$ PEFC employing silica-Nafion composite membranes is studied by obtaining its polarization curve as a function of load current. Figure 6 compares the polarization curves for the silica-Nafion composite and commercial Nafion-1135 membranes under fully wet conditions $(\approx 100 \% \mathrm{RH})$ at $60^{\circ} \mathrm{C}$ under ambient pressure. In all the experiments, the flow rates for both the fuel and the oxidant are fixed so as to preclude any water retention in the cell. The silica-Nafion composite membranes with varying silica content show better performance than those with Nafion membranes. Maximum proton conductivity with composite membranes is attained at an intermediate loading of silica, where silica improves water retention characteristic of the membrane without affecting the continuity of the proton conduction path in Nafion. It is apparent from the results shown in Fig. 6 that the resistance values of the cells with silica-Nafion composite membranes are lower as compared to those with Nafion membranes, the resistance being lowest

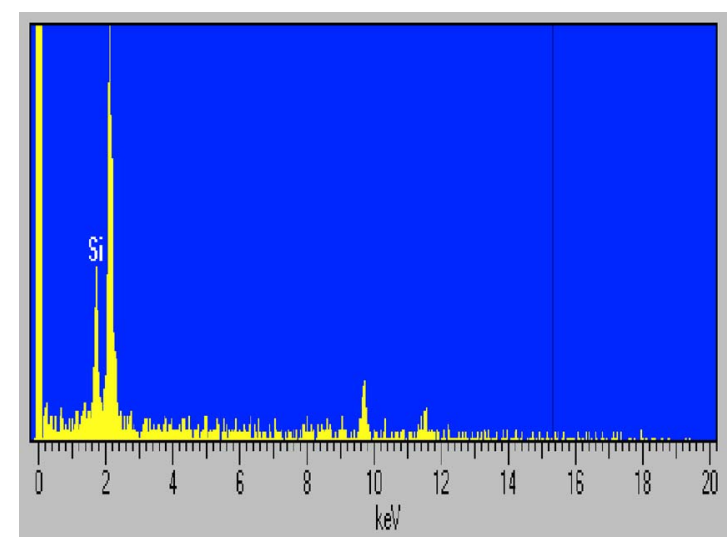

Figure 3. (Color online) EDAX spectrum for silica-Nafion composite membrane. for $10 \mathrm{wt} \%$ silica-Nafion composite membrane. The peak power density of $720 \mathrm{~mW} / \mathrm{cm}^{2}$ for the PEFC is achieved with a $10 \mathrm{wt} \%$ silica-Nafion composite membrane as compared to a $550 \mathrm{~mW} / \mathrm{cm}^{2}$ PEFC with Nafion-1135 membrane under identical operational conditions. It is obvious that the existence of silica as a proton conductor in the Nafion matrix assists the silica-Nafion composite membrane to achieve higher proton conductivity in relation to Nafion membrane. Proton conductivity in the silica-Nafion composite membrane is attributed to protons that are transferred through hydrogen bonding with water-filled ion pores. However, an excess of the silica phase could inhibit proton conduction in the membrane, disrupting the continuity of the proton conduction path in the Nafion membrane. ${ }^{15,30,31}$ Accordingly, the peak power density for the PEFC with a 15 wt \% silica-Nafion membrane is lower in relation to the PEFC with a $10 \mathrm{wt} \%$ silica-Nafion composite membrane.

The polarization curves for PEFCs with silica-Nafion composite and commercial Nafion-1135 membranes at $83 \%$ RH are presented in Fig. 7. It is seen that the performance curves for all the PEFCs exhibit lower performance as compared to Fig. 6, where the cells are in fully wet condition at about $100 \% \mathrm{RH}$. However, from the data in Fig. 7, it is observed that the PEFC with silica-Nafion composite membrane exhibits superior performance than those with unmodified Nafion membrane. The increase in peak power density of PEFCs with increasing content of silica in the silica-Nafion composite membrane is also noteworthy. The peak power density of $700 \mathrm{~mW} / \mathrm{cm}^{2}$ is achieved for $15 \mathrm{wt} \%$ silica-Nafion composite membrane compared to $460 \mathrm{~mW} / \mathrm{cm}^{2}$ for commercial Nafion-1135 membrane. This substantiates that the increased silica content helps water retention in the membrane.

The polarization curves for PEFCs with silica-Nafion composite membrane and Nafion-1135 at 66 and $31 \%$ RH values are presented in Fig. 8 and 9, respectively. It is seen from the data that the PEFCs with unmodified Nafion membrane exhibit poor performance in relation to the silica-Nafion composite membranes at varying $\mathrm{RH}$ values, as the former is poor in retaining water within its framework. The peak power densities obtained for PEFCs with Nafion-1135 at 

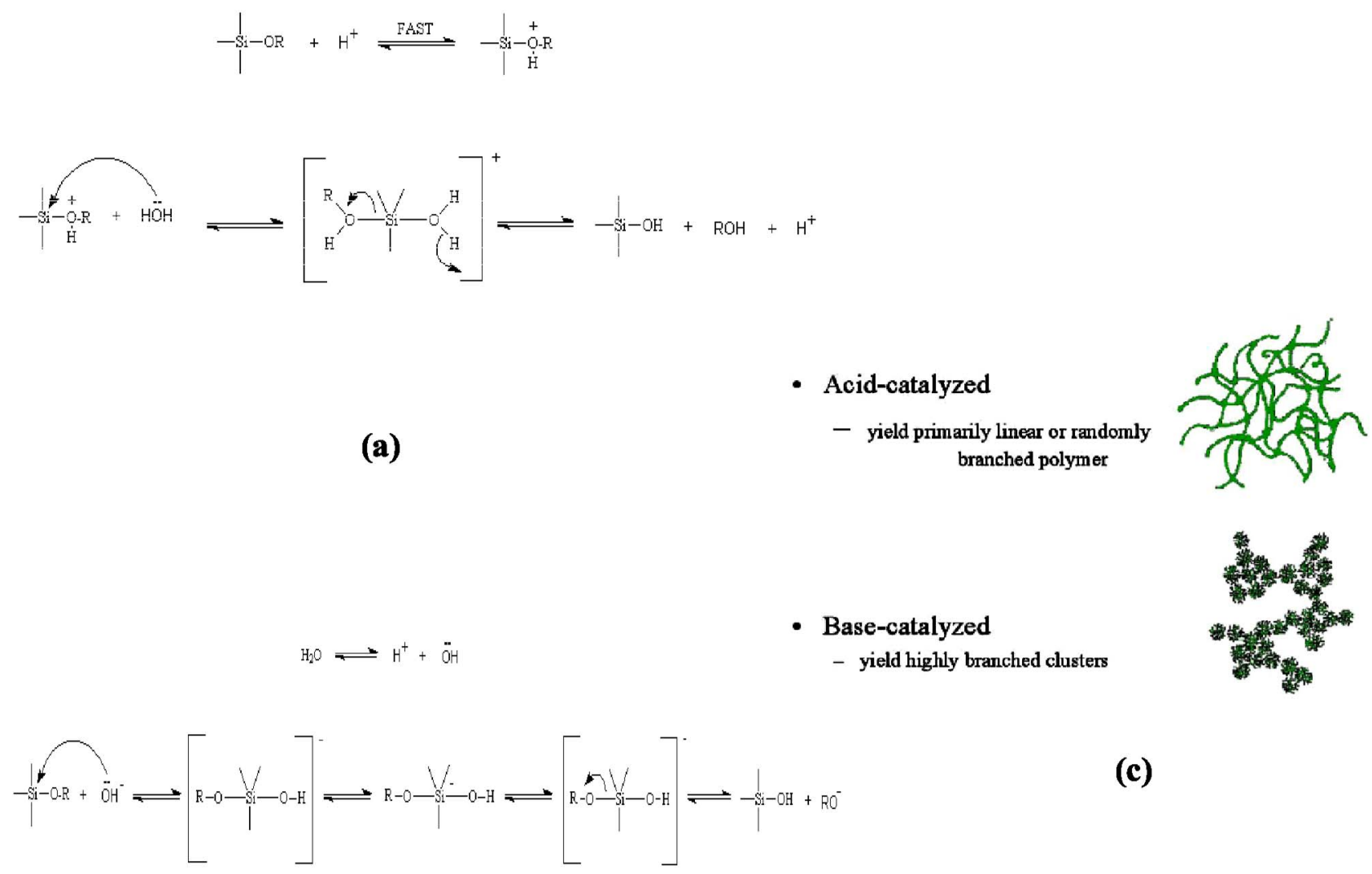

(c)

(b)

Figure 4. (Color online) Schematic description of (a) acid-catalyzed hydrolysis for the sol-gel reaction, (b) base-catalyzed hydrolysis for the sol-gel reaction, and (c) a summary of acid- and base-catalyzed sol-gel conditions.

66 and $31 \% \mathrm{RH}$ are around 300 and $80 \mathrm{~mW} / \mathrm{cm}^{2}$, respectively. By contrast, the PEFC performance improves with increased silica content in the silica-Nafion composite membrane at both RH values, as seen from the data in Fig. 8 and 9. The peak power densities of 625 and $420 \mathrm{~mW} / \mathrm{cm}^{2}$ are achieved at 66 and $31 \% \mathrm{RH}$, respectively, for PEFCs with silica-Nafion composite membranes.

The polarization behaviors of PEFCs with Nafion-1135 and silica-Nafion composite membranes under near-dry conditions $(\leq 18 \% \mathrm{RH})$ are shown in Fig. 10. At these RH values, the humidification of hydrogen gas is inapt to operate PEFCs with pure Nafion membranes as the PEFCs yield a peak power density of only about
$30 \mathrm{~mW} / \mathrm{cm}^{2}$ at the load current-density value of $100 \mathrm{~mA} / \mathrm{cm}^{2}$, primarily due to the poor conductivity of the Nafion membrane. By contrast, under identical conditions, PEFCs employing silica-Nafion composite membranes perform much better in relation to those with unmodified Nafion membranes. The performance of PEFCs with silica-Nafion composite membranes increases gradually with increasing silica content in the Nafion matrix. A peak power density of $300 \mathrm{~mW} / \mathrm{cm}^{2}$ is achieved at a load current-density value of $1200 \mathrm{~mA} / \mathrm{cm}^{2}$ for the PEFC employing a silica-Nafion composite membrane with 15 wt $\%$ silica while operating at $60^{\circ} \mathrm{C}$ under atmo-
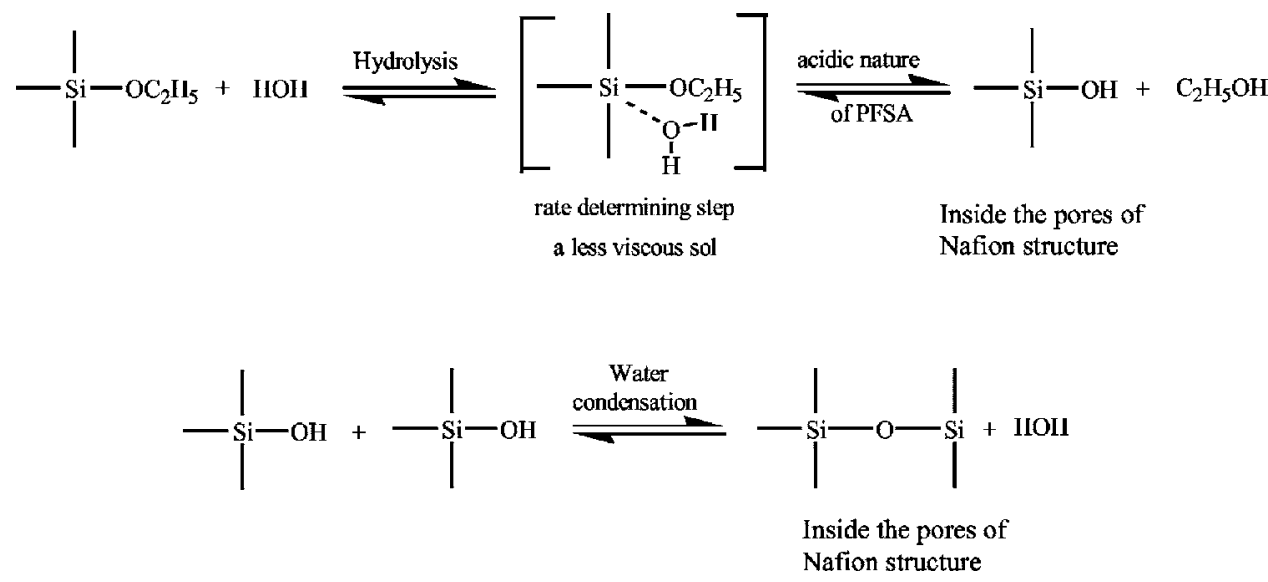

Figure 5. Schematic representation of the water hydrolysis to form a less viscous sol and subsequent condensation yielding hydroxide and oxide network of silica in the pores of PFSA matrix. 


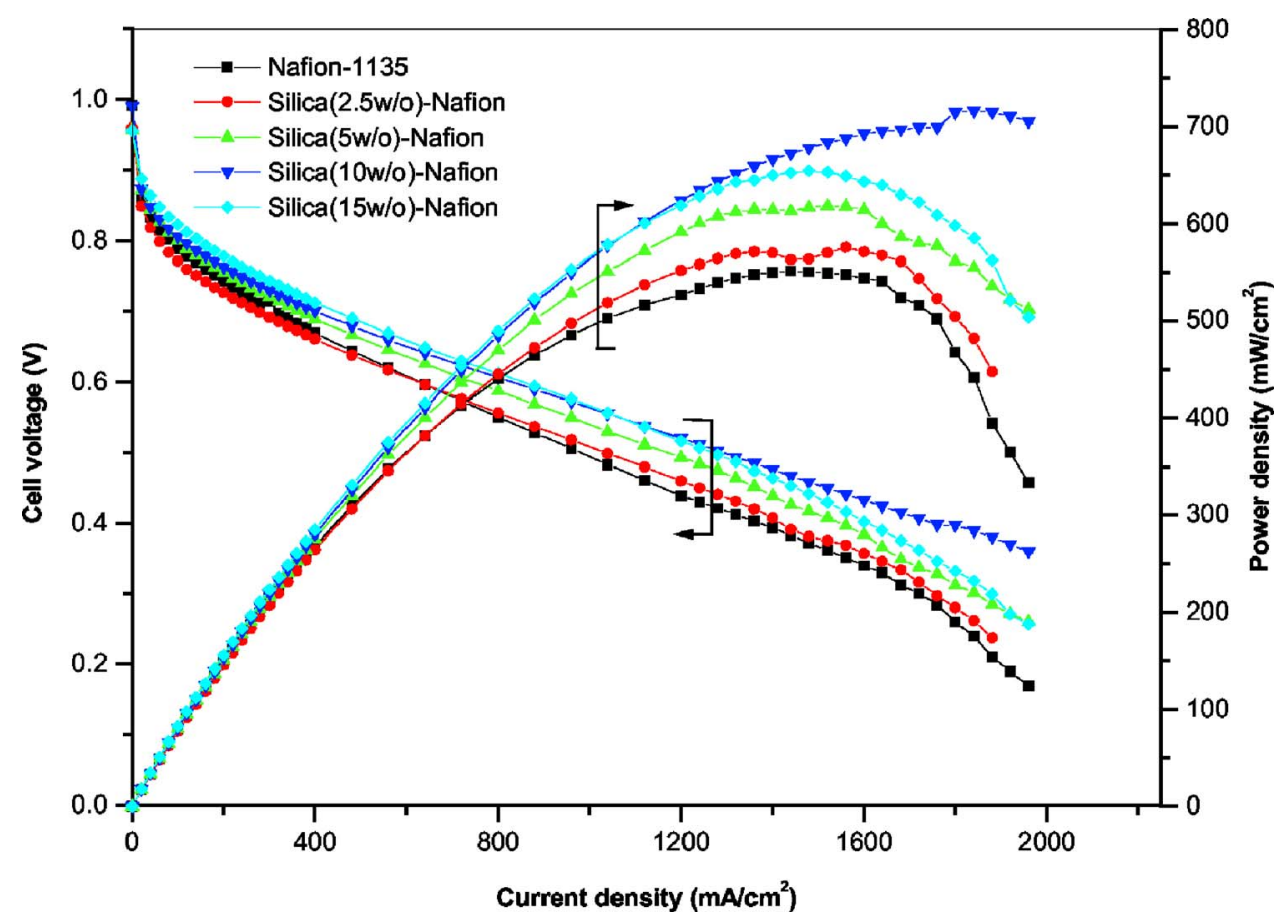

Figure 6. (Color online) Performance of $\mathrm{H}_{2} / \mathrm{O}_{2}$ PEFC with Nafion-1135 and silicaNafion composite membranes at $100 \%$ $\mathrm{RH}$ under atmospheric pressure operating at $60^{\circ} \mathrm{C}$.

spheric pressure. It is therefore quite obvious that PEFC performance is purely related to water management issues. In commercial Nafion membranes, due to the limited availability of water at the anode, electroosmotic drag of water from anode to cathode and insufficient water diffusion from cathode to anode cause the MEA to dehydrate. The membrane dehydration is manifested with an increase in ohmic resistance of the cell, leading to decreased cell performance. ${ }^{32}$ By contrast, in the case of composite Nafion membranes, due to water retention characteristics of the silica, such a problem is obviated. It may be that the positively charged silica particles counterbalance the negatively charged sulfonate groups present in the Nafion and enhance its hydrophilic character. The long-range coulombic attractive forces between protons and sulfonate groups are disrupted by the presence of positively charged silica particles in the membrane, facilitating the protons to readily

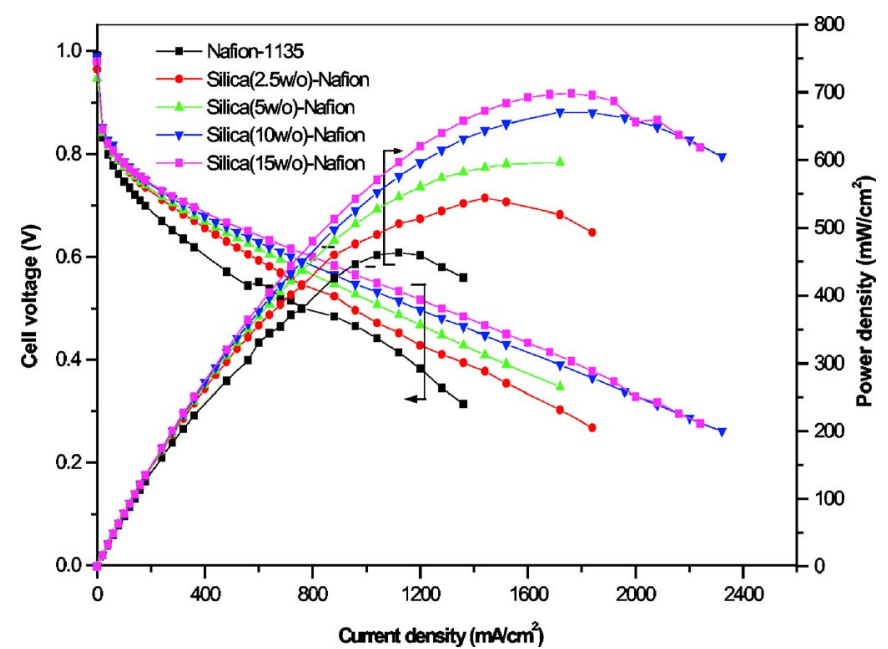

Figure 7. (Color online) Performance of $\mathrm{H}_{2} / \mathrm{O}_{2}$ PEFC with Nafion-1135 and silica-Nafion composite membranes at $83 \% \mathrm{RH}$ under atmospheric pressure operating at $60^{\circ} \mathrm{C}$. pass through the membrane pore fluids. Hence, the proton conductivity of the membrane is maintained, albeit it is lower than the proton-conductivity values at high $\mathrm{RH}$.

Adjemin et al. ${ }^{15}$ tested Nafion-115 and Nafion-silica composite membranes for $50 \mathrm{~h}$ of operation at $130^{\circ} \mathrm{C}$ under humidified conditions and at $3 \mathrm{~atm}$ pressure. It is found that the composite membrane had much higher stability at elevated temperature with a decline of about $5 \%$ in the performance. In this study, silica (15 wt \%)-Nafion composite membrane is considered for membrane stability test at near-dry conditions $(18 \% \mathrm{RH})$ and at $60^{\circ} \mathrm{C}$ under atmospheric pressure. The fuel cell power density is relatively stable with a decline of about $7 \%$ for $50 \mathrm{~h}$ of operation. Both the data are analyzed and the comparative performances are shown in Fig. 11.

Enhanced proton conduction in the silica-Nafion composite membranes of this study at low RH values could be visualized in light of the following discussion. Upon exposure to water, anhydrous silica, which has an isoelectric point, i.e., the $\mathrm{pH}$ at which the particles carry zero charge, of 2 is hydrated primarily in two ways: (i) physical adsorption of water molecules, including hydrogen bonding to surface oxygen ions but not dissociation, and (ii) chemisorption of water that dissociates, resulting in surface - $\mathrm{SiOH}$ groups. $^{33}$

The physical adsorption is represented by

$$
-\mathrm{SiOH}+\mathrm{H}^{+} \rightarrow-\mathrm{SiOH}---\mathrm{H}^{+}
$$

and chemisorption is represented by

$$
-\mathrm{SiOH}+\mathrm{H}^{+} \rightarrow-\mathrm{SiOH}_{2}^{+} \rightleftharpoons-\mathrm{Si}^{+}+\mathrm{H}_{2} \mathrm{O}
$$

Equation 4 is analogous to

$$
\mathrm{H}^{+}+\mathrm{Si}^{\mathrm{z}+}(\mathrm{OH})_{z}(\mathrm{aq})=\mathrm{Si}^{\mathrm{z}+}(\mathrm{OH})_{z-1}{ }^{+}(\mathrm{aq})+\mathrm{H}_{2} \mathrm{O}
$$

During the cell operation, protons are continuously generated at the anode and are driven through the membrane pore fluid, but the sulfonate groups remain largely unprotonated, even at low $\mathrm{pH}$ values. In the absence of essentially immobile counter cations in the pore fluid, this would retard the free migration of protons through the membrane, albeit the hydrophilic nature of the sulfonate groups would attract the water dipoles. If a positively charged surface, such as silica, is able to counterbalance the negative charge on the sulfonate groups, the hydrophilic region of the membrane is protonated 


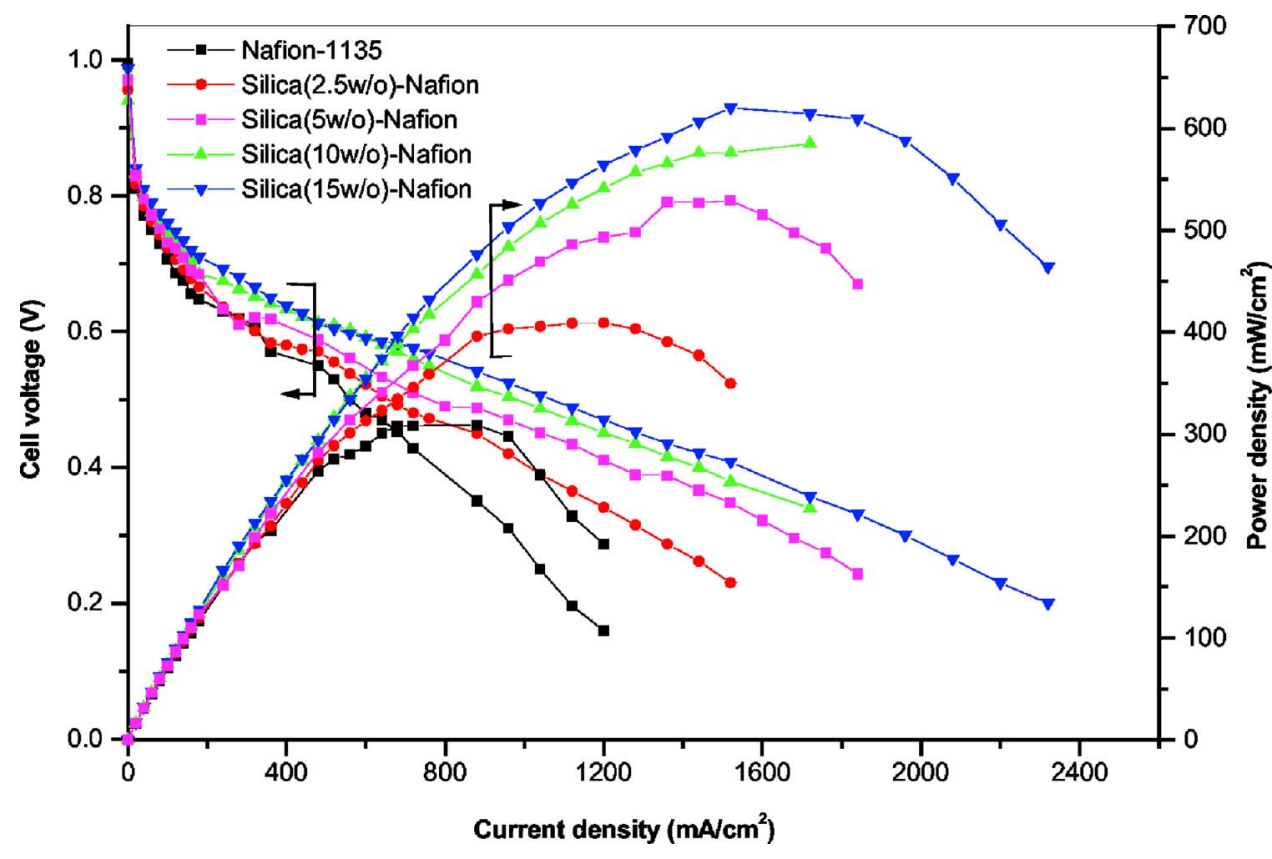

Figure 8. (Color online) Performance of $\mathrm{H}_{2} / \mathrm{O}_{2}$ PEFC with Nafion-1135 and silicaNafion composite membranes at $66 \% \mathrm{RH}$ under atmospheric pressure operating at $60^{\circ} \mathrm{C}$

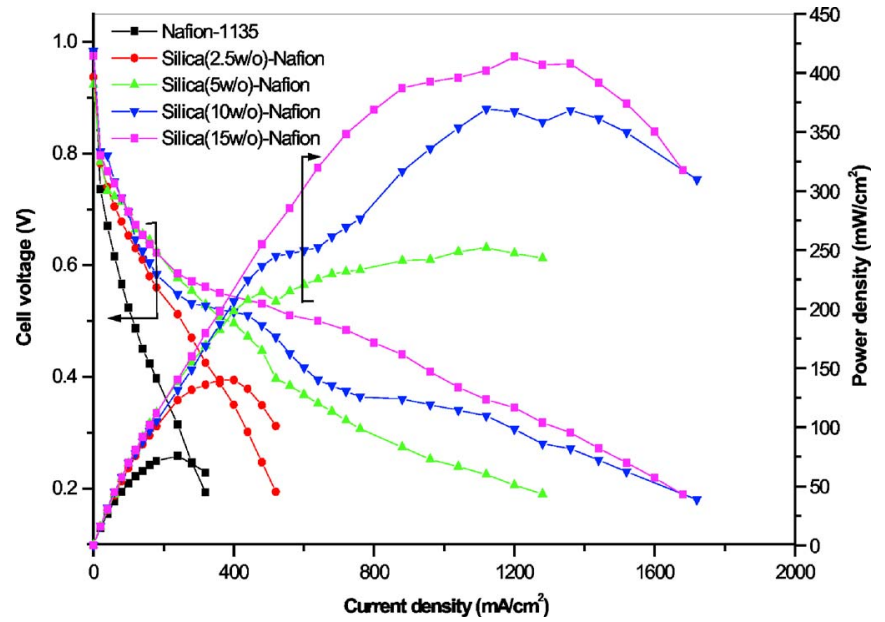

in the presence of both positively and negatively charged species within the membrane framework. This facilitates the unhindered migration of protons through the membrane. In other words, in the absence of fixed countercharges, the long-range coulombic attractive force of negatively charged sulfonate groups would tend to retain protons within the membrane, even as they are pushed through as a result of the external anode/cathode reactions. If the long-range coulombic attractive forces for protons are disrupted by the presence of fixed positively charged surfaces within the membrane, the protons pass more readily through the membrane.

In the silica-Nafion composite membrane, silica is characterized by a relatively high positive surface charge density and zeta potential due to proton adsorption. ${ }^{34}$ The high concentration of protons in the electrical double layer (EDL) is beneficial for the hydrophilicity of silica-Nafion composite membrane because water species forming the EDL are retained on the silica surface by the electric field. ${ }^{35}$

It is also apparent from the polarization curves at varying $\mathrm{RH}$

Figure 9. (Color online) Performance of $\mathrm{H}_{2} / \mathrm{O}_{2}$ PEFC with Nafion-1135 and silica-Nafion composite membranes at $31 \% \mathrm{RH}$ under atmospheric pressure values that the performance of PEFCs with silica-Nafion composite operating at $60^{\circ} \mathrm{C}$.

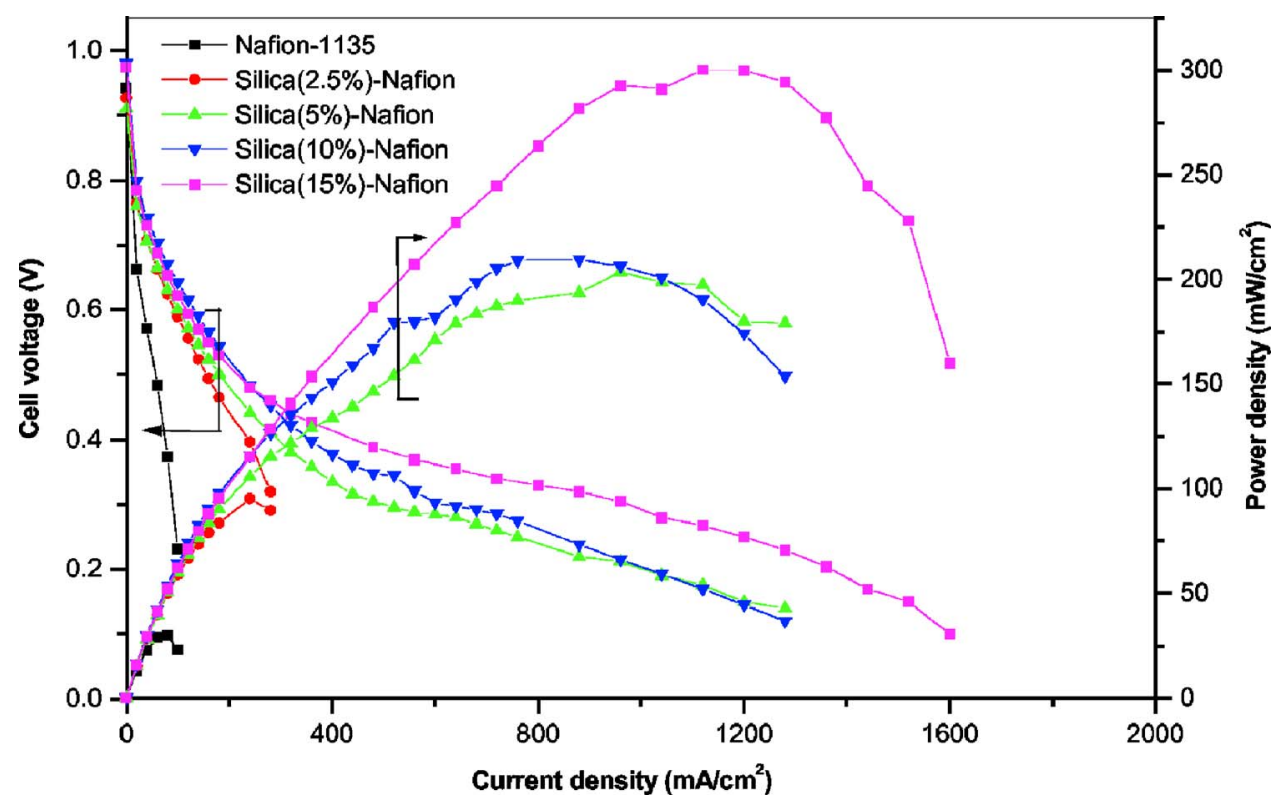

Figure 10. (Color online) Performance of $\mathrm{H}_{2} / \mathrm{O}_{2}$ PEFC with Nafion-1135 and silicaNafion composite membranes at $18 \% \mathrm{RH}$ under atmospheric pressure operating at $60^{\circ} \mathrm{C}$ 


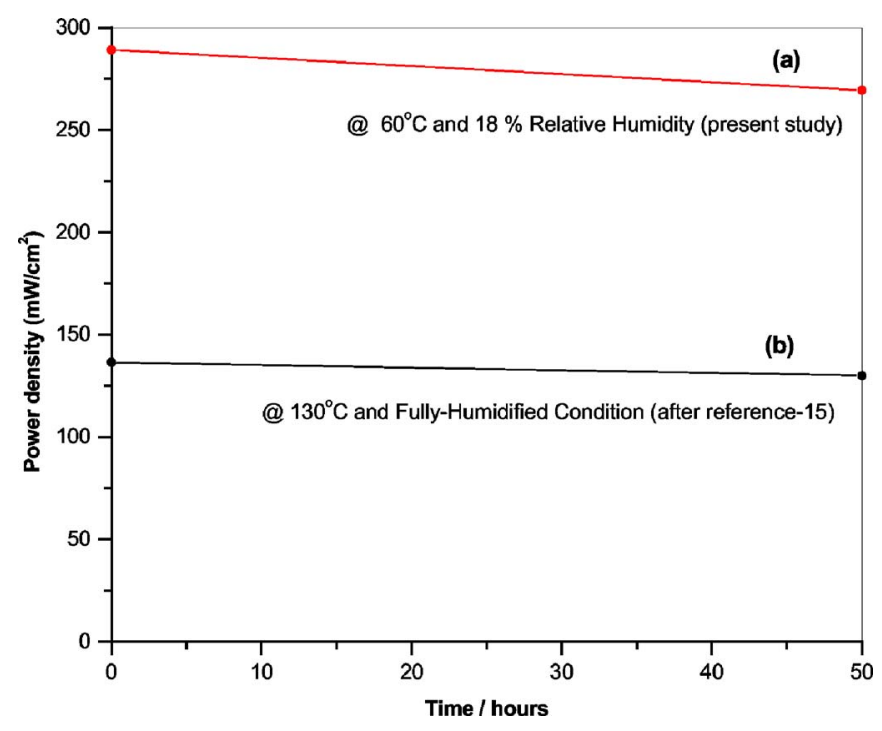

Figure 11. (Color online) (a) Durability test for PEFC with silica (15 wt $\%$ )-Nafion composite membrane under $18 \% \mathrm{RH}$ at $60^{\circ} \mathrm{C}$ and atmospheric pressure, and (b) durability data due to Adjemian et al. (Ref. 15) for a PEFC with silica (6 wt \%)-Nafion-115 membrane operating at $130^{\circ} \mathrm{C}$ at $3 \mathrm{~atm}$ pressure of $\mathrm{H}_{2}$ and $\mathrm{O}_{2}$ humidified at $130^{\circ} \mathrm{C}$.

membranes is improved at high load current densities. Decreased water flooding, which reduces the mass-transfer problem in silicaNafion composite membranes, may contribute to the improved performance of PEFCs. By contrast, at high load current densities, in the PEFCs with unmodified Nafion membranes, the water generation rates at the cathode are too high to substantially affect the effective area of the gas diffusion layers inside the electrode. However, the high water uptake by silica-Nafion composite membranes facilitates the product water in hydrating the membranes. ${ }^{36}$

Figure 12 shows the polarization curves for PEFCs with silicaNafion composite membranes under $100 \% \mathrm{RH}$ operating at $100^{\circ} \mathrm{C}$ at atmospheric pressure. It is seen that the performance curves for PEFCs with 10 wt \% silica-Nafion composite membranes yield a peak power density of $350 \mathrm{~mW} / \mathrm{cm}^{2}$. This clearly shows that PEFCs with silica-Nafion composite membrane perform better at elevated

\begin{tabular}{|c|c|c|c|c|c|}
\hline \multirow[b]{2}{*}{ Membrane } & \multirow[b]{2}{*}{$V_{0}(\mathrm{~V})$} & \multirow[b]{2}{*}{$b(\mathrm{~V})$} & \multirow[b]{2}{*}{$\begin{array}{c}R \\
\left(\Omega \mathrm{cm}^{2}\right)\end{array}$} & \multicolumn{2}{|c|}{$\begin{array}{l}\text { Current density } \\
\left(\mathrm{mA} / \mathrm{cm}^{2}\right)\end{array}$} \\
\hline & & & & at $0.7 \mathrm{~V}$ & at $0.4 \mathrm{~V}$ \\
\hline Nafion-1135 & 0.990 & 0.040 & 0.27 & 320 & 1400 \\
\hline $\begin{array}{l}\text { Silica }(2.5 \text { wt \%)- } \\
\text { Nafion }\end{array}$ & 0.965 & 0.036 & 0.24 & 280 & 1400 \\
\hline $\begin{array}{l}\text { Silica (5 wt \%)- } \\
\text { Nafion }\end{array}$ & 0.957 & 0.028 & 0.23 & 380 & 1560 \\
\hline $\begin{array}{l}\text { Silica (10 wt \%)- } \\
\text { Nafion }\end{array}$ & 0.990 & 0.036 & 0.20 & 400 & 1760 \\
\hline $\begin{array}{l}\text { Silica (15 wt \%)- } \\
\text { Nafion }\end{array}$ & 0.956 & 0.022 & 0.22 & 480 & 1640 \\
\hline
\end{tabular}

temperatures with little degradation in their performance, primarily due to water retention property of the membrane. The decrease in performance of silica (15 wt \%)-Nafion composite membrane could be due to electrode flooding by high water retention on the cathode side. PEFCs with Nafion-1135 are not able to deliver any sensible performance under similar operational conditions. Anecdotal information reflects hardly any difference in the mechanical strengths of pristine Nafion and silica-Nafion composite membranes.

To complement the polarization data on PEFCs evaluated under different conditions, the electrochemical kinetic parameters of the cell comprising Nafion-1135 and silica-Nafion composite membranes are also estimated by the following method and the data are presented in Tables II-VI. From the data in Tables II-VI, we found the open-circuit voltages (OCVs) for the PEFCs to be lower than $1 \mathrm{~V}$. This could be attributed to fuel crossover current density of about $2 \mathrm{~mA} / \mathrm{cm}^{2} .{ }^{37}$ The cell voltage $(V)$ vs current density $(i)$ behavior at varying RH values, in conjunction with the silica content in the composite membranes, are analyzed by fitting the data to

$$
V=V_{\mathrm{o}}-b \log i-i R
$$

In Eq. $6, V_{\mathrm{o}}$ is the observed open-cell potential, $b$ is the Tafel slope, and $i R$ accounts for the linear variation of overpotential with load current density due to ohmic resistance $(R)$.

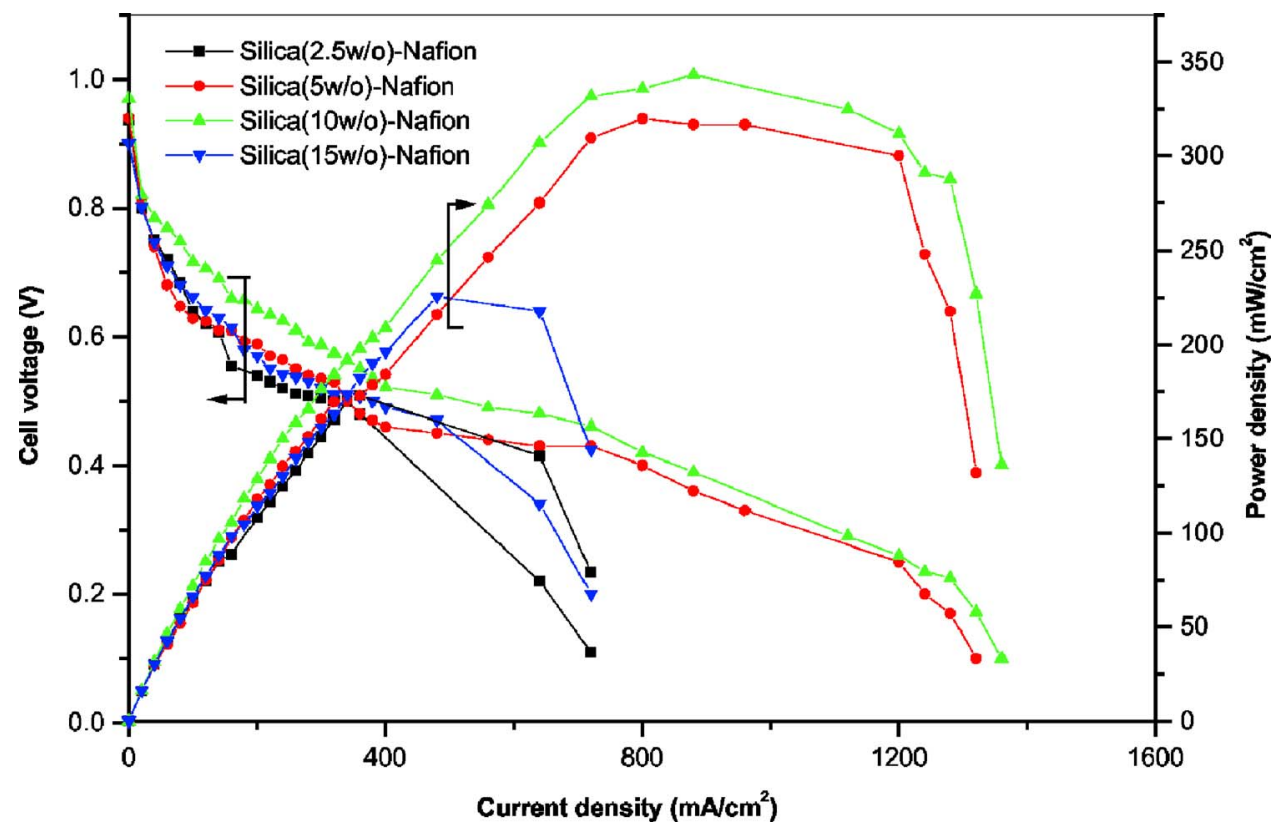

Figure 12. (Color online) Performance of $\mathrm{H}_{2} / \mathrm{O}_{2}$ PEFC with silica-Nafion composite membranes under $100 \% \mathrm{RH}$ operating at $100^{\circ} \mathrm{C}$ and atmospheric pressure. 
Table III. Electrochemical kinetic parameters for PEFC employing Nafion and silica-Nafion composite membranes with $83 \%$ RH at $60^{\circ} \mathrm{C}$ under atmospheric pressure.

\begin{tabular}{|c|c|c|c|c|c|}
\hline \multirow[b]{2}{*}{ Membrane } & \multirow[b]{2}{*}{$V_{0}(\mathrm{~V})$} & \multirow[b]{2}{*}{$b(\mathrm{~V})$} & \multirow{2}{*}{$\begin{array}{c}R \\
\left(\Omega \mathrm{cm}^{2}\right) \\
\end{array}$} & \multicolumn{2}{|c|}{$\begin{array}{l}\text { Current density } \\
\left(\mathrm{mA} / \mathrm{cm}^{2}\right)\end{array}$} \\
\hline & & & & at $0.7 \mathrm{~V}$ & at $0.4 \mathrm{~V}$ \\
\hline Nafion-1135 & 0.991 & 0.048 & 0.35 & 180 & 1160 \\
\hline $\begin{array}{l}\text { Silica }(2.5 \text { wt } \%)- \\
\text { Nafion }\end{array}$ & 0.965 & 0.036 & 0.28 & 280 & 1340 \\
\hline $\begin{array}{l}\text { Silica (5 wt \%)- } \\
\text { Nafion }\end{array}$ & 0.947 & 0.033 & 0.24 & 320 & 1500 \\
\hline $\begin{array}{l}\text { Silica }(10 \text { wt } \%)- \\
\text { Nafion }\end{array}$ & 0.989 & 0.039 & 0.21 & 340 & 1700 \\
\hline $\begin{array}{l}\text { Silica (15 wt \%)- } \\
\text { Nafion }\end{array}$ & 0.980 & 0.040 & 0.20 & 360 & 1760 \\
\hline
\end{tabular}

As seen from the data in Tables II-VI, the parameter $R$, which represents the ohmic resistance of the membrane, decreases with increasing silica content at high RH values. However, the effect is clearly pronounced at low RH values. At low RH values, the increase in resistance is significantly higher for unmodified Nafion membranes in relation to silica-Nafion composite membranes. This is a clear manifestation of the ability of silica to reduce membrane resistance due to its water-retention property. The Tafel slopes for the polarization curves comprising silica-Nafion composite membranes are lower as compared to the polarization curves for PEFCs with Nafion-1135 membranes. This signifies that an increase in the contact area for the electrodes with hydrated silica particles on the

Table IV. Electrochemical kinetic parameters for PEFC employing Nafion and silica-Nafion composite membranes with $66 \% \mathrm{RH}$ at $60^{\circ} \mathrm{C}$ under atmospheric pressure.

\begin{tabular}{|c|c|c|c|c|c|}
\hline \multirow[b]{2}{*}{ Membrane } & \multirow[b]{2}{*}{$V_{0}(\mathrm{~V})$} & \multirow[b]{2}{*}{$b(\mathrm{~V})$} & \multirow[b]{2}{*}{$\begin{array}{c}R \\
\left(\Omega \mathrm{cm}^{2}\right)\end{array}$} & \multicolumn{2}{|c|}{$\begin{array}{l}\text { Current density } \\
\left(\mathrm{mA} / \mathrm{cm}^{2}\right)\end{array}$} \\
\hline & & & & at $0.7 \mathrm{~V}$ & at $0.4 \mathrm{~V}$ \\
\hline Nafion-1135 & 0.994 & 0.056 & 0.40 & 110 & 750 \\
\hline $\begin{array}{l}\text { Silica }(2.5 \text { wt \%)- } \\
\text { Nafion }\end{array}$ & 0.956 & 0.043 & 0.35 & 130 & 1010 \\
\hline $\begin{array}{l}\text { Silica }(5 \mathrm{wt} \%)- \\
\text { Nafion }\end{array}$ & 0.940 & 0.044 & 0.27 & 150 & 1240 \\
\hline $\begin{array}{l}\text { Silica (10 wt \%)- } \\
\text { Nafion }\end{array}$ & 0.987 & 0.033 & 0.24 & 170 & 1440 \\
\hline $\begin{array}{l}\text { Silica (15 wt \%)- } \\
\text { Nafion }\end{array}$ & 0.970 & 0.046 & 0.22 & 220 & 1550 \\
\hline
\end{tabular}

Table V. Electrochemical kinetic parameters for PEFC employing Nafion and silica-Nafion composite membranes with $31 \%$ RH at $60^{\circ} \mathrm{C}$ under atmospheric pressure.

\begin{tabular}{|c|c|c|c|c|c|}
\hline \multirow[b]{2}{*}{ Membrane } & \multirow[b]{2}{*}{$V_{0}(\mathrm{~V})$} & \multirow[b]{2}{*}{$b(\mathrm{~V})$} & \multirow{2}{*}{$\begin{array}{c}R \\
\left(\Omega \mathrm{cm}^{2}\right) \\
\end{array}$} & \multicolumn{2}{|c|}{$\begin{array}{l}\text { Current density } \\
\qquad\left(\mathrm{mA} / \mathrm{cm}^{2}\right)\end{array}$} \\
\hline & & & & at $0.7 \mathrm{~V}$ & at $0.4 \mathrm{~V}$ \\
\hline Nafion-1135 & 0.980 & 0.073 & 2.00 & 30 & 180 \\
\hline $\begin{array}{l}\text { Silica }(2.5 \text { wt \%) - } \\
\text { Nafion }\end{array}$ & 0.937 & 0.045 & 0.96 & 65 & 340 \\
\hline $\begin{array}{l}\text { Silica }(5 \text { wt } \%) \text { - } \\
\text { Nafion }\end{array}$ & 0.923 & 0.042 & 0.55 & 100 & 520 \\
\hline $\begin{array}{l}\text { Silica }(10 \text { wt } \%)- \\
\text { Nafion }\end{array}$ & 0.983 & 0.050 & 0.35 & 100 & 640 \\
\hline $\begin{array}{l}\text { Silica (15 wt \%)- } \\
\text { Nafion }\end{array}$ & 0.975 & 0.057 & 0.28 & 100 & 970 \\
\hline
\end{tabular}

\begin{abstract}
Table VI. Electrochemical kinetic parameters for PEFC employing Nafion and silica-Nafion composite membranes with $18 \% \mathrm{RH}$ at $60^{\circ} \mathrm{C}$ under atmospheric pressure.
\end{abstract}

\begin{tabular}{|c|c|c|c|c|c|}
\hline \multirow[b]{2}{*}{ Membrane } & \multirow[b]{2}{*}{$V_{0}(\mathrm{~V})$} & \multirow[b]{2}{*}{$b(\mathrm{~V})$} & \multirow{2}{*}{$\begin{array}{c}R \\
\left(\Omega \mathrm{cm}^{2}\right) \\
\end{array}$} & \multicolumn{2}{|c|}{$\begin{array}{l}\text { Current density } \\
\left(\mathrm{mA} / \mathrm{cm}^{2}\right)\end{array}$} \\
\hline & & & & at $0.7 \mathrm{~V}$ & at $0.4 \mathrm{~V}$ \\
\hline Nafion-1135 & 0.942 & 0.049 & 4.30 & 15 & 80 \\
\hline $\begin{array}{l}\text { Silica }(2.5 \text { wt \%)- } \\
\text { Nafion }\end{array}$ & 0.927 & 0.045 & 1.51 & 40 & 230 \\
\hline $\begin{array}{l}\text { Silica }(5 \mathrm{wt} \%)- \\
\text { Nafion }\end{array}$ & 0.910 & 0.051 & 0.93 & 45 & 300 \\
\hline $\begin{array}{l}\text { Silica }(10 \text { wt } \%)- \\
\text { Nafion }\end{array}$ & 0.981 & 0.065 & 0.88 & 60 & 360 \\
\hline $\begin{array}{l}\text { Silica (15 wt \%)- } \\
\text { Nafion }\end{array}$ & 0.975 & 0.070 & 0.38 & 50 & 440 \\
\hline
\end{tabular}

surface of the composite membranes also improves the hydration of the ion-conducting phase in the electrode, which facilitates the electrochemical reaction kinetics on the electrodes.

In brief, this study indicates that silica-Nafion composite membranes exhibit lower resistance and hence PEFCs with silica-Nafion composite membranes can sustain higher load current densities, particularly at low RH values, in relation to the unmodified Nafion membranes. Hydrated silica provides better water retention in modified Nafion membranes than commercial Nafion membrane at reduced RH values. Besides, the impregnation of the silica into the nanopores of Nafion helps the composite membranes to be less susceptible to high temperature damage, mitigating the shrinkage of the membranes at low RH values. Dehydration of commercial Nafion membranes at elevated temperatures affects the pore structure, as reflected by their decreased proton conductivity. The presence of silica within the membranes apparently obviates these temperaturerelated structural changes, and their proton conductivity is retained even after thermal cycling at elevated temperatures. Accordingly, the present study provides an alternative route to fabricate silica-Nafion composite membranes with filler particles that absorb water and act as a water reservoir to keep the membrane wet even at low $\mathrm{RH}$ values. This helps the PEFCs to sustain periods of inlet-stream draught without excessive loss in membrane conductivity. Consequently, the humidification exigencies for PEFCs in an operating system are reduced, which in turn helps cut system complexity and hence cost.

\section{Conclusions}

The study describes a method of embedding silica particles in PFSA ionomer by a novel water hydrolysis process that circumvents the use of added acid while utilizing acidic characteristics of Nafion and polymerization reaction through a sol-gel route. This facilitates uniform and homogeneous $\mathrm{SiO}_{2}$ /siloxane cross linkages in the nanoporous Nafion structure. The composite Nafion membranes with inorganic fillers exhibit high affinity to water, enabling proton conduction in membrane electrolytes even at elevated temperatures and low $\mathrm{RH}$ values. This enables the PEFCs with the silica-Nafion composite membranes to be operated at elevated temperatures, even under low RH levels.

\section{Acknowledgments}

This study was carried out under the New Millennium Indian Technological Leadership Initiative (NMITLI) programme of CSIR, New Delhi. We thank R. A. Mashelkar, FRS, for his constant encouragement and support. A. K. Sahu is grateful to CSIR, New Delhi, for a Senior Research Fellowship. A. Jalajakshi is acknowledged for her assistance with fuel cell testing.

Central Electrochemical Research Institute assisted in meeting the publication costs of this article. 


\section{References}

1. J. Soler, M. J. Escudero, and L. Daza, Biofuels for Fuel Cells, P. Lens, P. Westermann, M. Haberbauer, and A. Moreno, Editors, pp. 282-284, IWA Publishing, London (2005)

2. C. Yang, P. Costamagna, S. Srinivasan, J. Benziger, and A. B. Bocarsly, J. Power Sources, 103, 1 (2001).

3. B. Gurau and E. S. Smotkin, J. Power Sources, 112, 339 (2002).

4. P. C. Rieke and N. E. Vanderborgh, J. Membr. Sci., 32, 313 (1987).

5. J. M. Song, S. Y. Cha, and W. M. Lee, J. Power Sources, 94, 78 (2001).

6. P. Costamagna, C. Yang, A. B. Bocarsly, and S. Srinivasan, Electrochim. Acta, 47, 1023 (2002).

7. K. Scott and A. K. Shukla, Biofuels for Fuel Cells, P. Lens, P. Westermann, M. Haberbauer, and A. Moreno, Editors, pp. 290-294, IWA Publishing, London (2005).

8. M.-K. Song, S.-B. Park, Y.-Taek Kim, K.-H. Kim, S.-K. Min, and H.-W. Rhee, Electrochim. Acta, 50, 639 (2004).

9. S. Panero, P. Fiorenza, M. A. Navarra, J. Romanowska, and B. Scrosati, J. Electrochem. Soc., 152, A2400 (2005).

10. L. C. Klein, Y. Daiko, M. Aparicio, and F. Damay, Polymer, 46, 4504 (2005).

11. N. Miyake, J. S. Wainright, and R. F. Savinell, J. Electrochem. Soc., 148, A898 (2001).

12. Z. Liu, B. Guo, J. Huang, L. Hong, M. Han, and L. M. Gan, J. Power Sources, 157, 207 (2005)

13. K. T. Adjemian, S. Srinivasan, J. Benziger, and A. B. Bocarsly, J. Power Sources, 109, 356 (2002).

14. M. Watanabe, H. Uchida, Y. Seki, and M. Emori, J. Phys. Chem. B, 102, 3129 (1998).

15. K. T. Adjemian, S. J. Lee, S. Srinivasan, J. Benziger, and A. B. Bocarsly, J. Electrochem. Soc., 149, A256 (2002).

16. P. Staiti, A. S. Aricò, V. Baglio, F. Lufrano, E. Passalacqua, and V. Antonucci, Solid State Ionics, 145, 101 (2001).

17. V. Ramani, H. R. Kunz, and J. M. Fenton, Electrochim. Acta, 50, 1181 (2005).
18. A. S. Aricò, V. Baglio, A. Di Blasi, and V. Antonucci, Electrochem. Commun., 5, 862 (2003).

19. D. H. Jung, S. Y. Cho, D. H. Peck, D. R. Shin, and J. S. Kim, J. Power Sources, 106, 173 (2002)

20. A. Sacca, A. Carbone, E. Passalacqua, A. D. Epifanio, S. Licoccia, E. Traversa, E. Sala, F. Traini, and R. Ornelas, J. Power Sources, 142, 385 (2005).

21. V. Baglio, A. S. Aricò, A. Di Blasi, V. Antonucci, P. L. Antonucci, S. Licoccia, E. Traversa, and F. Serraino Fiory, Electrochim. Acta, 50, 1241 (2005).

22. N. H. Jalani, K. Dunn, and R. Datta, Electrochim. Acta, 51, 553 (2005).

23. K. A. Mauritz, I. D. Stefanithis, S. V. Davis, R. W. Scheez, R. K. Pope, G. L. Wilkes, and H. H. Huang, J. Appl. Polym. Sci., 55, 181 (1995).

24. E. Chalkova, M. V. Fedkin, D. J. Wesolowski, and S. N. Lvov, J. Electrochem. Soc., 152, A1742 (2005).

25. R. Jiang, H. R. Kunz, and J. M. Fenton, J. Membr. Sci., 272, 116 (2006).

26. C. W. Lin, R. Thangamuthu, and P. H. Chang, J. Membr. Sci., 254, 197 (2005).

27. M. Aparicio, Y. Castro, and A. Duran, Solid State Ionics, 176, 333 (2005).

28. M. K. Ravikumar and A. K. Shukla, J. Electrochem. Soc., 143, 2601 (1996).

29. C. J. Brinker and G. W. Scherer, Sol-Gel Science: The Physics and Chemistry of Sol-Gel Processing, Academic Press, Inc., New York (1990).

30. B. Baradie, J. P. Dodelet, and D. Guay, J. Electroanal. Chem., 489, 101 (2000).

31. S.-H. Kwak, T.-H. Yang, C.-S. Kim, and K. H. Yoon, Solid State Ionics, 160, 309 (2003).

32. J. R. Atkins, S. C. Savett, and S. E. Creager, J. Power Sources, 128, 201 (2004).

33. G. A. Parks, Chem. Rev. (Washington, D.C.), 1964, 177.

34. M. V. Fedkin, X. Y. Zhou, J. D. Kubicki, A. V. Bandura, S. N. Lvov, M. L. Machesky, and D. J. Wesolowski, Langmuir, 19, 3797 (2003).

35. E. Chalkova, M. B. Pague, M. V. Fedkin, D. J. Wesolowski, and S. N. Lvov, J. Electrochem. Soc., 152, A1035 (2005).

36. Y. M. Kim, S. H. Choi, H. C. Lee, M. Z. Hong, K. Kim, and H. I. Lee, Electrochim. Acta, 49, 4787 (2004)

37. J. Larminie and A. Dicks, Fuel Cell Systems Explained, pp. 53-56, Wiley, New York (2003). 